\title{
Comparison between H-FABP \& troponin i as outcome predictors in sepsis and sepsis-related LV dysfunction
}

\author{
HM Sherif*, M AbulWafa, A Gaber, W Sami \\ From ESICM LIVES 2015 \\ Berlin, Germany. 3-7 October 2015
}

\section{Background}

The emerging cardiac biomarker heart-type fatty acidbinding protein (H-FABP) is rapidly released from cardiomyocytes into the circulation shortly after the onset of the cell damage. Few studies have investigated its utility in critically ill patients and whether it offers a similar and even superior power to the conventional cardiac biomarkers.

\section{Objective}

Estimation of the prognostic significance of H-FABP as an independent risk factor in patients with septic shock and the prevalence of sepsis related myocardial dysfunction, in comparison to Troponin I.

\section{Methods}

Fifty ICU patients (pts.) with sepsis were enrolled in this study. All pts. were subjected to APACHE II score as a clinical scoring system on admission and every $24 \mathrm{~h}$ during the ICU stay. All pts. were also investigated for the serum levels of both H-FABP and Troponin I during the first $24 \mathrm{~h}$ after admission. Using modified Simpson's method, echocardiographic left ventricular (LV) end-diastolic volume (LVEDV), LV end-systolic volume (LVESV) and LV \% ejection fraction (\%EF) were calculated on admission and after $24 \mathrm{~h}$.

\section{Results}

The pts. were divided into 12 pts. (mean: $50.2 \pm 21$ years) suffering from sepsis with stable hemodynamics (group-1), and 38 patients (mean: $58.4 \pm 19.2$ years) with septic shock (group-2). Compared to group-1, H-FABP of group-2 showed a significant higher values $(76.3 \%$ vs. $33.3 \%$ of pts., $P<0.05)$, but the data was comparable for Troponin I. In both groups; compared to pts. with negative H-FABP, pts.

Faculty of Medicine, Cairo University, Critical Care Medicine, Cairo, Egypt with positive H-FABP showed a significant increased number of pts. ( $66 \%$ vs. $34 \%, P<0.05$ ), but the data was comparable for Troponin I. Compared to group-1, APACHE II score in group-2 showed significantly higher values (31.9 \pm 9.3 vs.16.2 $\pm 7.1, P<0.001)$. In both groups, the positive H-FABP pts. had significant higher APACHE II score than the negative H-FABP pts. $(32.3 \pm 8.7$ vs. $20.1 \pm 11$ of pts., $P<0.001)$, but the data was comparable for Troponin $\mathrm{I}$. Despite the positive H-FABP pts. and negative H-FABP pts. were comparable for LV\%EF after $24 \mathrm{~h}$ of admission, but the positive H-FABP pts. showed significant increased LV volumes (LVEDV $=105$ vs. $77 \mathrm{ml}, P<0.05$, and LVESV $=49$ vs. $33 \mathrm{ml}, P<0.05)$, respectively. The mortality rate was significantly higher in group- 2 vs. group-1 (78.9\% vs. $41.7 \%, P<0.05)$. H-FABP was a better prognostic marker than Troponin I; it showed a higher prevalence of mortality ( $88 \%$ vs. $35 \%, P<0.001)$ with good correlation $(\mathrm{r}=$ $0.54, P<0.05)$. Multivariate regression analysis showed that the number of organ dysfunction with positive $\mathrm{H}$ FABP pts. raised the odds of mortality 7.5 times $(P<0.05)$.

\section{Conclusions}

$\mathrm{H}-\mathrm{FABP}$ is a good prognostic marker and an independent risk factor for mortality in patients with severe sepsis and septic shock than Troponin I. During the first 24 hours of ICU admission, the positive H-FABP patients showed significant relation with sepsis-related LV systolic myocardial dysfunction.

Published: 1 October 2015

doi:10.1186/2197-425X-3-S1-A753

Cite this article as: Sherif et al:: Comparison between H-FABP \& troponin i as outcome predictors in sepsis and sepsis-related LV dysfunction. Intensive Care Medicine Experimental 2015 3(Suppl 1):A753. (c) 2015 Sherif et al.; This is an Open Access article distributed under the terms of the Creative Commons Attribution License (http:// creativecommons.org/licenses/by/4.0), which permits unrestricted use, distribution, and reproduction in any medium, provided the original work is properly cited. 